Jurnal MAKSIPRENEUR, Vol. V, No. 2, Juni 2016, hal. 38 - 45

\title{
PENGENDALIAN PERSEDIAAN TABLET TAMBAH DARAH DI UPT FARMASI DAN ALAT KESEHATAN KOTA YOGYAKARTA
}

\author{
Kristy Tri Wardhani (kristywardhani@gmail.com) \\ Fakultas Ekonomi Universitas Proklamasi 45 Yogyakarta
}

\begin{abstract}
Women of childbearing age and pregnant women are susceptible to nutritional deficiencies of iron that can cause bleeding during childbirth. It is one of the causes of the high maternal mortality rate in Indonesia. The government, especially the Department of Health has a role in meeting the needs of the iron tablet, especially in the management of medicines. This study aims to estimate the amount of iron tablet needs for the period 2015, according to data distribution in 2013 and 2014; comparing needs iron tablet planned with the realization of the distribution in 2013 and 2014; as well as the correlations between the number of visits in the clinic by the number of prescriptions or the distribution of iron tablet needs. Quantitative research using the data distribution, transfer and planning proposals iron tablet, as well as the number of health center visits prescriptions. Data processing includes forecasting distributions based on the trend with seasonal index, forecasting needs with the method of consumption, and correlation test. The tools used are Microsoft Excel Data Analysis menu. The results of the estimated distribution in 2015 to 18 health centers with a buffer stock of $20 \%$ is 487607 tablets that can be met from the stock early in 2015. The proportion of the distribution of the iron tablet planning for 18 health centers in 2013 was 57.48\%, and in 2014 amounted to 53, 28\% are caused not all pregnant women check-up and receive iron tablet in the clinic. Correlation coefficient values $<0.4$ indicate a weak correlation between the amount of iron tablet needs with the number of visits recipes
\end{abstract}

Keywords: Tablet blood added, forecasting, inventory.

\section{PENDAHULUAN}

Untuk melindungi wanita usia subur dan ibu hamil dari kekurangan gizi dan mencegah terjadinya anemia gizi besi, maka ibu hamil dan wanita usia subur perlu mengonsumsi tablet tambah darah. Peran pemerintah dalam memenuhi kebutuhan tablet tambah darah untuk wanita usia subur dan ibu hamil tercantum dalam Peraturan Menteri Kesehatan Republik Indonesia Nomor 97 tahun 2014 tentang Pelayanan Kesehatan Masa Sebelum Hamil, Masa Hamil, Persalinan, dan Masa Sesudah Melahirkan, Penyelenggaraan Pelayanan Kontrasepsi, serta Pelayanan Kesehatan Seksual, dan Peraturan Menteri Kesehatan Republik Indonesia Nomor 88 Tahun 2014 tentang Standar Tablet Tambah Darah Bagi Wanita Usia Subur dan Ibu Hamil.

Pemerintah, terutama Dinas Kesehatan berperan dalam pengelolaan obat-obatan termasuk tablet tambah darah. Pengelolaan yang dimaksud meliputi perencanaan kebutuhan, perencanaan pengadaan, penerimaan, penyimpanan, pendistribusian, pelaporan, monitoring dan evaluasi. 
Pengendalian persediaan tablet tambah darah harus dilakukan agar ketersediaannya dapat memenuhi kebutuhan sesuai yang sudah direncanakan. Beberapa hal yang dapat menyebabkan persediaan menjadi tidak optimal diantaranya yaitu: persediaan yang terlalu banyak atau terlalu sedikit, dan penyerapan di lapangan yang menyimpang jauh dari jumlah yang sudah direncanakan (terlalu banyak atau terlalu sedikit). Pengendalian persediaan dapat dilakukan agar tablet tambah darah dapat terjamin ketersediaannya dengan mempertimbangkan masa daluarsa obat, sehingga dapat meminimalkan tablet tambah darah yang kedaluwarsa dan harus dimusnahkan.

Dari pantauan selama ini, didapati bahwa jumlah yang diadakan berdasarkan perencanaan seringkali tidak terserap oleh puskesmas. Tablet tambah darah dan obat lain yang tidak digunakan tersebut tentu saja menimbulkan kerugian material apabila mencapai batas daluarsanya. Selain itu, obat yang tidak terserap pada tahun perencanaan dapat menyebabkan penggunaan gudang menjadi kurang efisien dan perlu dievaluasi untuk perencanaan periode berikutnya.

Penelitian ini bertujuan untuk memperkirakan jumlah kebutuhan tablet tambah darah untuk periode tahun 2015, berdasarkan data distribusi tahun 2013 dan 2014; membandingkan kebutuhan tablet tambah darah yang direncanakan dengan realisasi distribusi tahun 2013 dan 2014; serta mengetahui korelasi antara jumlah kunjungan resep di puskesmas dengan jumlah distribusi atau kebutuhan tablet tambah darah.

\section{TINJAUAN PUSTAKA}

Sistem pengendalian persediaan dapat didefinisikan sebagai serangkaian kebijakan pengendalian untuk menentukan tingkat persediaan yang harus dijaga, kapan pesanan untuk menambah persediaan harus dilakukan dan berapa besar pesanan harus diadakan. Sistem ini menentukan dan menjamin tersedianya persediaan yang tepat dalam kuantitas waktu yang tepat.

Pengertian manajemen logistik menurut Bowersox (2004), adalah suatu ilmu bagaimana mendesain dan mengurus suatu sistem untuk mengawasi arus dan penyimpanan yang strategis bagi material, suku cadang dan barang jadi agar dapat diperoleh manfaat maksimum bagi organisasi.

Menurut Seto (2004), fungsi-fungsi logistik terdiri dari perencanaan dan penentuan kebutuhan, penganggaran, pengadaan, penerimaan dan penyaluran, pemeliharaan, penghapusan, dan pengawasan. Apabila lemah dalam perencanaan, misalnya dalam penentuan suatu item barang yang berlebih atau kurang maka akan mengacaukan suatu siklus manajemen logistik secara keseluruhan mulai dari pemborosan dalam penganggaran, kadaluarsa atau menumpuk.

Menurut Peraturan Menteri Kesehatan Republik Indonesia Nomor 30 Tahun 2014 tentang Standar Pelayanan Kefarmasian di Puskesmas, pengelolaan obat dan bahan medis pakai habis merupakan salah satu kegiatan pelayanan kefarmasian, yang dimulai dari perencanaan, permintaan, penerimaan, penyimpanan, pendistribusian, pengendalian, pencatatan dan pelaporan serta pemantauan dan evaluasi. Tujuannya adalah untuk menjamin kelangsungan ketersediaan dan keterjangkauan obat dan bahan medis pakai habis yang efisien, efektif dan rasional, meningkatkan kompetensi/ kemampuan tenaga kefarmasian, mewujudkan sistem informasi manajemen, dan melaksanakan pengendalian mutu pelayanan.

Untuk memesan suatu barang sampai barang itu datang diperlukan jangka waktu yang bisa bervariasi dari beberapa jam sampai beberapa bulan. Perbedaan waktu antara saat memesan sampai saat barang datang dikenal dengan istilah waktu tenggang (lead 
time). Waktu tenggang sangat dipengaruhi oleh ketersediaan dari barang itu sendiri dan jarak lokasi antara pembeli dan pemasok berada.

Terdapat tiga metode yang digunakan dalam menilai persediaan, yaitu first in first out (FIFO), last in first out (LIFO), dan rata-rata tertimbang. Metode penilaian persediaan yang digunakan bisa berbeda dengan metode penempatan persediaan secara fisik. Manajemen distribusi memfokuskan pada arus keluar dari produk. Manajemen rantai pasokan sangat penting untuk mengurangi investasi persediaan. Perpindahan barang yang cepat adalah kuncinya. Tolok ukur keberhasilan rantai pasokan adalah meminimalkan biaya, waktu tunggu, pengiriman terlambat, dan kekurangan persediaan serta meningkatkan tingkat layanan.

Peramalan (forecasting) adalah suatu seni dan ilmu pengetahuan dalam memprediksi peristiwa pada masa mendatang. Peramalan akan melibatkan mengambil data historis (seperti penjualan tahun lalu) dan memproyeksikan mereka ke masa yang akan datang dengan model matematika. Perencanaan yang efektif baik dalam jangka pendek dan jangka panjang bergantung pada peramalan permintaan atas produk perusahaan.

Menurut Herjanto (2007), model peramalan asosiatif biasanya mempertimbangkan beberapa variabel yang terkait dengan kuantitas yang akan diprediksikan. Ketika variabel yang terkait ini telah diketahui, model statistika akan dibuat dan digunakan untuk meramalkan barang terkait.

Persamaan regresi adalah salah satu cara untuk menggambarkan sifat dari hubungan di antara 2 (dua) variabel. Garis regresi bukan hubungan "sebab akibat", namun menggambarkan hubungan di antara variabel-variabel. Persamaan regresi menunjukkan bagaimana salah satu variabel terkait dengan nilai dan perubahan dalam variabel lainnya.

Cara lainnya untuk mengevaluasi hubungan di antara 2 (dua) variabel adalah dengan menghitung koefisien terhadap korelasi (coefficient of correlation). Ukuran ini mencerminkan derajat atau kekuatan hubungan linear. Biasanya diidentifikasikan sebagai $r$, koefisien korelasi dapat menjadi banyak angka diantara +1 dan -1 .

\section{METODE PENELITIAN}

Penelitian ini dilakukan di UPT Farmasi dan Alat Kesehatan Kota Yogyakarta, dengan menggunakan data jumlah distribusi tablet tambah darah ke puskesmas, data jumlah perencanaan kebutuhan tablet tambah darah yang direncanakan oleh puskesmas, data mutasi persediaan tablet tambah darah (table 1), dan data jumlah kunjungan resep puskesmas. Data yang digunakan adalah data tahun 2013 dan 2014 sebagaimana dalam tabel 1 berikut ini. 
Tabel 1

Mutasi Tablet Tambah Darah Tahun 2013 dan 2014

\begin{tabular}{|c|c|c|c|c|c|c|}
\hline Tahun & $\begin{array}{c}\text { Jenis Tablet } \\
\text { Tambah } \\
\text { Darah }\end{array}$ & Stok Awal & Penerimaan & \multicolumn{2}{|c|}{ Pengeluaran } & Stok Akhir \\
\hline \multirow{4}{*}{2013} & Tablet Besi II & 64,800 & 157,800 & Pusk & 194,400 & 28,200 \\
\hline & Tablet & & & Pusk & 271,700 & \multirow{2}{*}{$1,289,000$} \\
\hline & Hemafort & 184,600 & 181,000 & Non Pusk & 4,900 & \\
\hline & Jumlah & 849,400 & 938,800 & & 471,000 & $1,317,200$ \\
\hline \multirow{4}{*}{2014} & Tablet Besi II & 28,200 & 24,000 & Pusk & 52,200 & 0 \\
\hline & Tablet & \multirow{2}{*}{$1,289,000$} & \multirow{2}{*}{240,000} & Pusk & 388,900 & \multirow{2}{*}{$1,137,100$} \\
\hline & Hemafort & & & Non Pusk & 3,000 & \\
\hline & Jumlah & $1,317,200$ & 264,000 & & 444,100 & $1,137,100$ \\
\hline
\end{tabular}

Sumber: Dara Laporan Mutasi Obat UPT Farmakes tahun 2013 dan 2014

Untuk meramalkan jumlah kebutuhan tablet tambah darah tahun 2015 dilakukan analisis peramalan berdasarkan data historis, yaitu data distribusi bulanan tablet tambah darah selama tahun 2013 dan 2014. Penerapan garis trend dilakukan dengan metode matematis kuadrat terkecil dengan indek musiman bulanan. Data dasar yang digunakan adalah data distribusi antara Bulan Desember 2013 dan Januari 2014. Persamaan trend yang diperoleh dalam bentuk $\mathrm{Y}=\mathrm{a}+\mathrm{bX}$ digunakan untuk memperkirakan jumlah distribusi masing-masing puskesmas, yang apabila dikompilasi akan menjadi perkiraan distribusi UPT Farmasi dan Alat Kesehatan tahun 2015. Perkiraan jumlah tablet tambah darah yang harus diadakan, dihitung dengan mempertimbangkan persediaan awal, rencana persediaan akhir, serta waktu daluarsa tablet tambah darah.

Dalam penelitian ini, analisis regresi digunakan untuk mencari koefisien korelasi antara jumlah kunjungan resep puskesmas dengan jumlah distribusi tablet tambah darah.

\section{HASIL DAN PEMBAHASAN}

Penelitian ini bertujuan untuk memperkirakan jumlah kebutuhan tablet tambah darah untuk periode tahun 2015, berdasarkan data distribusi tahun 2013 dan 2014; membandingkan kebutuhan tablet tambah darah yang direncanakan dengan realisasi distribusi tahun 2013 dan 2014; serta mengetahui korelasi antara jumlah kunjungan resep di puskesmas dengan jumlah distribusi atau kebutuhan tablet tambah darah.

Hasil penelitian ini dapat digunakan untuk memprediksi setidaknya 5 (lima) sampai 6 (enam) bulan periode setelah Desember 2014, karena persamaan trend dimungkinkan tidak sesuai dengan kenyataan dan kondisi pada saat tersebut, misalnya adanya perubahan trend atau pemberlakuan kebijakan baru yang bersifat dinamis.Persamaan trend untuk masing-masing puskesmas disajikan pada tabel 2.

Tabel 2

Persamaan Trend

\begin{tabular}{|c|c|c|}
\hline No. & Puskesmas & Persamaan Trend untuk Peramalan \\
\hline 1 & I & $\mathrm{y}=5085.9-73.87 \mathrm{x}$ \\
\hline 2 & II & $\mathrm{y}=6341.3-81.304 \mathrm{x}$ \\
\hline 3 & III & $\mathrm{y}=1085.5+55.826 \mathrm{x}$ \\
\hline 4 & IV & $\mathrm{y}=1745.7-39.652 \mathrm{x}$ \\
\hline 5 & V & $\mathrm{y}=6679.3-181.35 \mathrm{x}$ \\
\hline 6 & VI & $\mathrm{y}=2275.7-7.3913 \mathrm{x}$ \\
\hline 7 & VII & $\mathrm{y}=1314.5-8.8261 \mathrm{x}$ \\
\hline
\end{tabular}




\begin{tabular}{|c|c|c|}
\hline 8 & VIII & $\mathrm{y}=2473.2-59.522 \mathrm{x}$ \\
\hline 9 & IX & $\mathrm{y}=1263-26.043 \mathrm{x}$ \\
\hline 10 & $\mathrm{X}$ & $\mathrm{y}=2958.7-91.696 \mathrm{x}$ \\
\hline 11 & XI & $\mathrm{y}=1135.5+2.8261 \mathrm{x}$ \\
\hline 12 & XII & $\mathrm{y}=1358-14.304 \mathrm{x}$ \\
\hline 13 & XIII & $\mathrm{y}=1305.8-8.1304 \mathrm{x}$ \\
\hline 14 & XIV & $\mathrm{y}=1439.1-17.13 \mathrm{x}$ \\
\hline 15 & XV & $\mathrm{y}=3820.7-91.652 \mathrm{x}$ \\
\hline 16 & XVI & $\mathrm{y}=3422.8-73.826 \mathrm{x}$ \\
\hline 17 & XVII & $\mathrm{y}=1538+2.9565 \mathrm{x}$ \\
\hline 18 & XVIII & $\mathrm{y}=2256.2-62.826 \mathrm{x}$ \\
\hline
\end{tabular}

Sumber: lampiran 10

Hasil perhitungan dari persamaan trend adalah jumlah perkiraan distribusi masing-masing puskesmas per bulan. Perkiraan distribusi masing-masing puskesmas untuk tahun 2015 adalah penjumlahan dari perkiraan distribusi setiap bulan dari Januari hingga Desember 2015jumlah total perkiraan distribusi berdasarkan indeks musiman bulanan untuk 18 (delapan belas) puskesmas disajikan dalam tabel 3

Tabel 3

Perkiraan Distribusi dengan Indeks Musiman untuk 18 Puskesmas

\begin{tabular}{|c|c|}
\hline $\begin{array}{c}\text { Bulan } \\
\text { Tahun 2015) }\end{array}$ & $\begin{array}{c}\text { Jumlah Total Perkiraan Distribusi Berdasarkan Indeks } \\
\text { Musiman Bulanan Untuk 18 (Delapan Belas) } \\
\text { Puskesmas }\end{array}$ \\
\hline Jan & 57,873 \\
\hline Feb & 17,825 \\
\hline Mar & 22,142 \\
\hline Apr & 17,140 \\
\hline Mei & 31,311 \\
\hline Jun & 19,701 \\
\hline Jul & 19,346 \\
\hline Agu & 15,843 \\
\hline Sep & 17,977 \\
\hline Okt & 18,293 \\
\hline Nov & 24,407 \\
\hline Des & 24,970 \\
\hline Jumlah & 286,828 \\
\hline
\end{tabular}

Sumber : lampiran 11

Jumlah perkiraan kebutuhan tablet tambah darah untuk tahun 2015 adalah jumlah perkiraan distribusi (286.828 tablet), ditambah dengan buffer stock sebesar 20\% (57.366 tablet), ditambah dengan waktu tunggu (lead time) selama 6 (enam) bulan (143.414 tablet), yaitu sebanyak 487.607 tablet.Jumlah tablet tambah darah yang perlu diadakan, dapat dihitung dengan memperhitungkan persediaan awal dan rencana persediaan akhir. Dari data yang diperoleh, diketahui bahwa persediaan akhir tahun 2014 (merupakan persediaan awal tahun 2015) adalah sebanyak 1.137.100 tablet dengan masa daluarsa Juni 2016, Februari 2017 dan September 2019. Bila direncanakan persediaan akhir adalah sebanyak perkiraan kebutuhan tablet tambah darah untuk tahun 2015, yaitu sebanyak 487.607 tablet, maka jumlah tablet tambah darah yang perlu diadakan dapat 
dihitung dari perkiraan kebutuhan, ditambah rencana persediaan akhir, dikurangi dengan persediaan awal, yaitu sebanyak 975.214 tablet.

Dari data tahun 2013, ada 2 (dua) puskesmas yang jumlah distribusinya lebih dari jumlah perencanaannya, yaitu Puskesmas II dan Puskesmas V. Sedangkan 16 (enam belas) puskesmas lainnya, data distribusinya jauh lebih sedikit dari jumlah perencanaannya. Serapan masing-masing puskesmas sangat bervariasi, mulai dari 22,35\% hingga 115,69\%. Dari data keseluruhan 18 (delapan belas) puskesmas, dapat diamati bahwa tablet tambah darah yang terserap atau digunakan hanya 57,48\% dari jumlah total perencanaan. Dan sisanya, $42,52 \%$ tidak terserap, menjadi persediaan akhir di UPT Farmasi dan Alat Kesehatan, dan menjadi bahan pertimbangan dalam pengadaan tablet tambah darah periode berikutnya, dengan mempertimbangkan masa daluarsanya.

Dari data 2014, dapat diamati bahwa hanya 1 (satu) dari 18 (delapan belas) puskesmas yang distribusinya melebihi perencanaannya, yaitu Puskesmas XII. Serapan masing-masing puskesmas masih sangat bervariasi dari $28,63 \%$ hingga $139,78 \%$. Secara keseluruhan, serapan tablet tambah darah tahun 2014 hanya 53,28\%, artinya tablet tambah darah yang tidak terserap sebanyak $46,72 \%$.

Dari hasil uji korelasi, dapat diketahui bahwa hubungan antara jumlah kunjungan resep dengan jumlah distribusi tablet tambah darah memiliki pengaruh yang relatif kecil. Pada Puskesmas VI, Puskesmas XIII, dan Puskesmas XVII, nilai koefisien korelasi menunjukkan nilai negatif, yang dapat dimaknai bahwa apabila jumlah kunjungan resep meningkat, maka distribusi tablet tambah darah justru mengalami penurunan. Hal ini disebabkan kemungkinan jumlah peningkatan kunjungan resep yang terjadi bukanlah resep yang mengandung tablet tambah darah. Sedangkan pada 15 (lima belas) puskesmas yang lain, koefisien korelasi bernilai positif, yang artinya peningkatan jumlah kunjungan resep akan diikuti oleh peningkatan distribusi tablet tambah darah. Secara umum, nilai koefisien korelasi pada 18 (delapan belas puskesmas) bernilai < 0,4, menunjukkan bahwa korelasi antara jumlah kunjungan resep dengan jumlah distribusi tablet tambah darah sangat lemah.

Pengelolaan obat di UPT Farmasi dan Alat Kesehatan dilakukan dengan metode FIFO (First In First Out), menggunakan kartu stok yang memberikan informasi mengenai jumlah persediaan, riwayat penerimaan dan pengeluaran barang serta masa daluarsanya, serta didukung dengan pencatatan secara komputerisasi. Pengadaan obat secara umum dilakukan 1 (satu) kali dalam 1 (satu) tahun, namun tidak menutup kemungkinan untuk melakukan pengadaan lebih dari 1 (satu) kali dengan mempertimbangkan tingkat kebutuhan dan anggaran yang tersedia. Persediaan tablet tambah darah di UPT Farmasi tidak pernah mengalami kekosongan, dan selalu tersedia dengan masa daluarsa yang relatif panjang (sekitar 3 hingga 4 tahun), dan permintaan puskesmas selalu terpenuhi. Distribusi obat dan perbekalan farmasi dari UPT Farmasi dan Alat Kesehatan ke puskesmas dilakukan setiap bulan.

\section{KESIMPULAN DAN SARAN}

A. Kesimpulan

Data hasil penelitian ini dapat digunakan sebagai pembanding dan bahan evaluasi untuk pengendalian persediaan tablet tambah darah tahun 2015 di UPT Farmasi dan Alat Kesehatan. Persediaan tablet tambah darah yang ada di UPT Farmasi dan Alat Kesehatan diperkirakan dapat memenuhi kebutuhan tablet tambah darah selama tahun 2015. Secara umum, dari data tahun 2013 dan 2014, jumlah distribusi tablet tambah 
darah dari UPT Farmasi dan Alat Kesehatan ke puskesmas jauh lebih sedikit daripada jumlah yang direncanakan. Jumlah kunjungan resep puskesmas memiliki hubungan yang rendah/lemah terhadap jumlah distribusi tablet tambah darah atau sebaliknya. Secara umum, peningkatan jumlah kunjungan resep akan mengakibatkan peningkatan jumlah distribusi tablet tambah darah, namun nilainya tidak signifikan.

\section{B. Saran}

Berdasarkan hasil, pembahasan dan kesimpulan yang telah dikemukakan, maka dapat disarankan penggunaan data hasil penelitian ini sebagai pembanding dan bahan evaluasi untuk pengendalian persediaan tablet tambah darah tahun 2015 di UPT Farmasi dan Alat Kesehatan. Pada pihak-pihak yang terlibat dalam perencanaan kebutuhan tablet tambah darah, dapat memanfaatkan hasil penelitian ini untuk pengendalian persediaan obat, khususnya tablet tambah darah, sehingga dapat dicapai jumlah persediaan dengan tingkat kecukupan yang optimal, serta untuk penelitian selanjutnya dapat menggunakan metode analisis yang berbeda dan lebih mendalam terkait pengendalian persediaan tablet tambah darah.

\section{DAFTAR PUSTAKA}

Aditama, Tjandra Yoga. 2002. Manajemen Administrasi Rumah Sakit. Edisi 2. Jakarta: UI-Press.

Bowersox, Donald J. 2004. Manajemen Logistik Integrasi Sistem-Sistem Manajemen Fisik dan Material. Jakarta: Bumi Aksara.

Dainur. 1995. Kegiatan KIA di Puskesmas dan permasalahannya. Jakarta: EGC.

Dirjen Binakefarmasian dan Alat Kesehatan Kemenkes RI.2010. Pedoman Pengelolaan Perbekalan Farmasi di Rumah Sakit.

Fajarwati. 2011. Gambaran Sistem Pengelolaan Penyimpanan Barang Logistik di Unit Logistik Sub Bagian Pelaksana Rumah Tangga RSUD Budhi Assih Tahun 2011. Depok: Skripsi UI.

Fauzy, Akhmad. 2012. Statistika Kesehatan. Jakarta: Ardana Media.

Heizer, Jay. Render, Barry. 2014. Manajemen Operasi: Manajemen Keberlangsungan dan Rantai Pasokan. Jakarta: Salemba Empat.

Herjanto, Eddy. 2007. Manajemen Operasi. Jakarta: Grasindo.

Irmawati.2014. Manajemen Logistik Farmasi di Rumah Sakit. Jakarta: Institut Ilmu Kesehatan-University Press.

Maria, Irene. 2010. Analisa Pelaksanaan Penyimpanan Perbekalan Farmasi di Gudang Farmasi RSUD Kota Bekasi Tahun 2010, Skipsi, Program Sarjana Fakultas Kesehatan Masyarakat. Jakarta: UI Press.

PAHO/ WHO. 2007. Manajemen dan Logistik Bantuan Kemanusiaan dalam Sektor Kesehatan. Cetakan I. Jakarta: EGC.

Peraturan Daerah Kota Yogyakarta Nomor 10 Tahun 2008 tentang Pembentukan, Susunan, Kedudukan dan Tugas Pokok Dinas Daerah.

Peraturan Kepala Badan Pengawas Obat dan Makanan Republik Indonesia Nomor 12 Tahun 2015 Tentang Pengawasan Pemasukan Obat dan Makanan ke dalam Wilayah Indonesia.

Peraturan Menteri Kesehatan Republik Indonesia Nomor 30 Tahun 2014 Tentang Standar Pelayanan Kefarmasian di Puskesmas. 
Peraturan Menteri Kesehatan Republik Indonesia Nomor 88 Tahun 2014 Tentang Standar Tablet Tambah Darah Bagi Wanita Usia Subur dan Ibu Hamil.

Peraturan Menteri Kesehatan Republik Indonesia Nomor 97 Tahun 2014 Tentang Pelayanan Kesehatan Masa Sebelum Hamil, Masa Hamil, Persalinan, dan Masa Sesudah Melahirkan, Penyelenggaraan Pelayanan Kontrasepsi, serta Pelayanan Kesehatan Seksual Selama Hamil.

Peraturan Walikota Yogyakarta Nomor 111 Tahun 2011 Tentang Pembentukan, Susunan, Kedudukan, Fungsi Rincian Tugas Unit Pelaksana Teknis Farmasi dan Alat Kesehatan Pada Dinas Kesehatan Kota Yogyakarta.

Seto, Soerjono. 2004. Manajamen Farmasi. Surabaya: Airlangga University Press. Subagya. 1994. Manajemen Logistik. Jakarta: CV Haji Masaguna. 